\title{
ELISA for Determination of Human Growth Hormone: Recognition of Helix 4 Epitopes
}

\author{
Juliana F. Moura, ${ }^{1}$ Luiz DeLacerda, ${ }^{2}$ Romolo Sandrini, ${ }^{2}$ Fernanda M. Borba, ${ }^{2}$ Denise N. Castelo, ${ }^{2}$ \\ Elis R. Sade, ${ }^{1}$ Sandra Sella, ${ }^{3}$ João C. Minozzo, ${ }^{3}$ Luis G. Callefe, ${ }^{1}$ and Bonald C. Figueiredo ${ }^{1 *}$ \\ ${ }^{1}$ Center for Molecular Genetics and Childhood Cancer Research (CEGEMPAC), Rua Agostinho Leão Júnior, \\ 400 Alto da Glória, Curitiba, PR, Brazil \\ ${ }^{2}$ Division of Pediatrics Endocrinology, Department of Pediatrics, \\ Federal University of Paraná, Curitiba, PR, Brazil \\ ${ }^{3}$ Center for Research and Production of Immunoglobulins (CPPI), Piraquara, PR, Brazil
}

Received 19 September 2003; revised 16 December 2003; accepted 22 December 2003

\begin{abstract}
Human growth hormone (hGH) signal transduction initiates with a receptor dimerization in which one molecule binds to the receptor through sites 1 and 2. A sandwich enzyme-linked immunosorbent assay was developed for quantifying hGH molecules that present helix 4 from binding site 1. For this, horse anti-rhGH antibodies were eluted by an immunoaffinity column constituted by sepharoserhGH. These antibodies were purified through a second column with synthetic peptide correspondent to $h G H$ helix 4 , immobilized to sepharose, and used as capture antibodies. Those that did not recognize synthetic peptide were used as a marker antibody. The working range was of 1.95 to $31.25 \mathrm{ng} / \mathrm{mL}$ of hGH. The intra-assay coefficient of variation (CV) was between $4.53 \%$ and $6.33 \%$, while the interassay CV was between $6.00 \%$ and $8.27 \%$. The recovery range was between $96.0 \%$ to $103.8 \%$. There was no cross-reactivity with human prolactin. These features show that our assay is an efficient method for the determination of hGH.
\end{abstract}

\section{INTRODUCTION}

Diagnosis of growth hormone deficiency (GHD) is usually based upon assessment of anthropometric parameters in patients who present reduced levels of growth hormone in response to a pharmacological test [1].

Most of the commercially available immunoassays do not describe the precise epitope of human growth hormone (hGH) recognized by its primary antibodies, neither do they take into consideration the possibility of an assessment of the biological activity of the hGH isoforms. One single hGH molecule binds to two receptors through hGH binding sites 1 and $2[2,3]$. To this date, only a few immunoassays have employed antibodies that recognize one of these sites. One of these assays, which has successfully employed an antibody that recognizes GH binding site 2, associated with binding of hGH binding protein (GHBP) to binding site 1, was estimated to reveal hGH biological activity, and it was proposed as an immunofunctional assay (IFA) [4]. According to the authors, their assay has revealed mutated GH isoforms with impaired biological activities, involving either a modification in hGH binding site 2 or a mutated hGH binding site 1 that is unable to bind to GHBP. This IFA and other bioassays $[5,6,7,8]$ were used to quantify GH bioactive isoforms that are absent in Kowarski syndrome [9]. The main features of this syndrome are the high plasma hGH levels, determined with immunoassays using polyclonal antibodies, low insulin-like growth factor-I (IGF-I) and IGF-binding protein-3 (IGFBP-3) concentrations, and a good response to recombinant human growth hormone (rhGH) in the first months of treatment [10].

An IFA usually presents low immunoreactivity to mutant hGH isoforms, which, by contrast, may be in normal or high levels revealed by an assay that employs a primary polyclonal antibody. These assays have employed different markers. The immunoradiometric assay (IRMA) [11], immunofluorometric assay (IFMA) [12], and immunochemiluminometric assay (ICMA) [13] use radioisotope, fluorescent, or chemiluminescent compounds conjugated to the marker antibody, respectively. The authors of [11, $12,13]$ have reported GH serum levels as low as 0.015 , 0.02 , and $0.005 \mathrm{ng} / \mathrm{mL}$.

This work was designed to develop a sensitive and specific horseradish peroxidase (HRPO) enzyme-linked immunosorbent assay (ELISA) for hGH determination. Several small sequences of amino acids form the binding site 1 domain [14]. In the present study, one of the synthetic peptides with 16 amino acids, which include a sequence of 6 residues required for hGH binding site 1 [15], was the best peptide to purify a polyclonal antibody to hGH. 


\section{MATERIALS AND METHODS}

\section{Animal immunization}

One adult female horse was immunized with rhGH (Genotropin, Pharmacia Diagnostics AB, Upsala, Sweden) through subcutaneous applications at 15-day interval. The emulsion for the first injection was prepared using $750 \mu \mathrm{g}$ of rhGH dissolved in $2.5 \mathrm{~mL}$ of $0.05 \mathrm{M}$ phosphate buffer saline pH 7.4 (PBS) and $2.5 \mathrm{~mL}$ of Freund's complete adjuvant. The remaining 7 applications were prepared using Freund's incomplete adjuvant.

Optimal animal immunization was indicated by high serum concentration of anti-rhGH employing two different protocols, immunodiffusion test and ELISA. Animal sera were obtained $(1.5 \mathrm{~L})$ and immunoglobulins were precipitated in a saturated ammonium sulfate solution.

\section{Purification of anti-rhGH antibodies}

Specific anti-rhGH antibodies were purified through immunoaffinity columns. One gram of cyanogen bromide-activated sepharose (CNBr-sepharose) was coupled to $21.5 \mathrm{mg}$ of rhGH according to the manufacturer's instructions (Pharmacia). Conjugated sepharose-rhGH was packed into a $6.0 \mathrm{~mL}$ polystyrene column, washed and filled with PBS and $0.05 \%$ sodium azide, and maintained at $4^{\circ} \mathrm{C}$.

Aliquots of horse immunoglobulins dissolved in PBS circulated through the column at a flow rate of $20 \mathrm{~mL} / \mathrm{h}$ overnight at $4^{\circ} \mathrm{C}$. Afterwards, the column was washed with PBS until the absorbance $(280 \mathrm{~nm})$ of the eluted solution had returned to baseline. Recovery of the immunoglobulins bound to the sepharose-rhGH column was performed washing the column with $0.1 \mathrm{M}$ glycine$\mathrm{HCl} 0.15 \mathrm{M} \mathrm{NaCl}, \mathrm{pH} 5.0$, until an immunoglobulin peak had been obtained. Finally, the column was washed with PBS until the absorbance returned to baseline. Solution containing anti-rhGH antibodies was dialyzed overnight at $4^{\circ} \mathrm{C}$ in $\mathrm{PBS}$.

\section{Antibodies anti-helix 4 of hGH}

A number of peptides were generously provided by the Peptide Laboratory from UNIFESP (São Paulo, SP). The technique used by this laboratory was reported by Kates and Albericio [16]. We have prepared several immunoaffinity columns using several synthetic peptides designed according to the sequences found in helix 4 and other parts of hGH, but only one was appropriate for anti-rhGH purification. The selected peptide extends from amino acid residue 166 to 181 and does not include disulfide bridges, but encompasses 6 residues (Asp171, Lys172, Thr175, Phe176, Arg178, and Ile179) that are important for the binding of hGH to the human GH receptor (hGHR) [15] and 12 residues different from the respective portion of human prolactin [17].

Each synthetic peptide $(20 \mathrm{mg})$ was immobilized to $1.0 \mathrm{~g}$ of CNBr-sepharose according to the manufacturer's instructions (Pharmacia). Sepharose-helix 4 peptide was packed into a $6.0 \mathrm{~mL}$ polystyrene column, washed and filled with PBS and $0.05 \%$ sodium azide. This column was maintained at $4^{\circ} \mathrm{C}$.

Aliquots with purified anti-rhGH antibodies circulated through the sepharose-helix 4 peptide column (or through other columns prepared with other peptides) at a flow rate of $20 \mathrm{~mL} / \mathrm{h}$. Unbound anti-rhGH antibodies that did not recognize the helix 4 peptide were eluted and separated to be conjugated with HRPO (later used as second anti-hGH antibody). The column was washed with PBS until the absorbance $(280 \mathrm{~nm})$ of the eluate returned to baseline. Samples of eluted anti-rhGH were dialysed overnight at $4^{\circ} \mathrm{C}$ in PBS. To collect anti-helix 4 peptide antibodies, the column $\mathrm{pH}$ was reduced with $0.1 \mathrm{M}$ glycine$\mathrm{HCl} 0.15 \mathrm{M} \mathrm{NaCl}, \mathrm{pH} 5.0$, and the eluted solution was after a while dialysed at $4^{\circ} \mathrm{C}$ in PBS, overnight. Finally, the immunoaffinity column was washed with PBS until the absorbance of the eluted solution returned to baseline.

\section{Preparation of anti-rhGH antibodies for ELISA}

Anti-rhGH antibodies that did not recognize the helix 4 peptide, eluted from the affinity column, were conjugated to HRPO according to the procedure reported by Nakane and Kawaoi [18].

A 96-well Nunc MaxiSorp plate (Nalge Nunc International, Roskilde, Denmark) was coated overnight at $4^{\circ} \mathrm{C}$ with $100 \mu \mathrm{L}$ of a $10 \mu \mathrm{g} / \mathrm{mL}$ solution of anti-helix 4 antibodies in $0.05 \mathrm{M}$ carbonate buffer, $\mathrm{pH}$ 9.6. Afterwards, the wells were washed with wash buffer $(0.05 \%$ Tween 20 in saline). Each well was filled with $120 \mu \mathrm{L}$ of blocking buffer ( $2 \%$ casein in PBS) and the plate was incubated for 1 hour at $37^{\circ} \mathrm{C}$. After washing, serial dilution of $\mathrm{rhGH}$ ( $125 \mathrm{ng} / \mathrm{mL}$ to $0.98 \mathrm{ng} / \mathrm{mL})$ in dilution buffer $(0.25 \% \mathrm{ca}-$ sein, $0.05 \%$ Tween 20 , PBS) was added to the wells starting from the first row. After incubating the plate for 1 hour at $37^{\circ} \mathrm{C}$, it was washed and anti-rhGH HRPO conjugated in dilution buffer was added to the wells with final dilutions of $1: 250,1: 500,1: 1000,1: 2000,1: 4000$, and $1: 8000$, starting from the first column (left to right). After incubation for 1 hour at $37^{\circ} \mathrm{C}$, the solution was removed and the wells were washed at least six times and $100 \mu \mathrm{L}$ of an orthophenilenediamine solution $(0.33 \mathrm{mg} / \mathrm{mL}$ in $0.5 \mathrm{M}$ citrate buffer, $\mathrm{pH} 5.2$, and $0.4 \%$ hydrogen peroxide) were added to each well. After 15 minutes at room temperature, protected from light, the enzymatic reaction was stopped through the addition of $20 \mu \mathrm{L}$ of $2 \mathrm{M}$ sulfuric acid. The absorbance (492 nm) was measured using a Bio-Tek ELX 800 reader.

\section{Samples}

This study was approved by the Ethics Committee from the Hospital of Clinics from the Federal University of Parana, and serum samples from 73 boys (10.9 \pm 3.0 years) and 36 girls $(10.1 \pm 3.2$ years $)$ were collected after obtaining written consent from their parents. The patients were submitted to the $\mathrm{GH}$ test $(\mathrm{GH}$ released 
after clonidine application) according to the established protocol for growth retardation at the Division of Pediatric Endocrinology of Hospital of Clinics. Time course of sample collection for each patient: baseline (before clonidine), 60, 90, and 120 minutes after clonidine administration.

Sandwich ELISA was used to quantify hGH from these patients. The absorbance values from each serum were plotted against the standard curve obtained with rhGH and the results were compared with the previously known hGH measurements from IRMA (MaiaClone, Biodata Diagnostics, Rome, Italy).

\section{RESULTS}

\section{Production, purification, and titration of antibodies}

Serum from rhGH-immunized horse was tested by immunodiffusion in the presence of $\mathrm{rhGH} 1 \mathrm{mg} / \mathrm{mL}$ and the results were positive up to $1: 4$ dilutions. After treating the animal with one extra injection of rhGH, serum titres were reanalyzed by ELISA two weeks later, when adequate immunization was revealed by titres of $1: 256000$.

After ammonium sulfate precipitation and dialysis of whole immunoglobulins, these polyclonal antibodies were purified by sepharose-rhGH column and the final concentration was $1.6 \mathrm{mg} / \mathrm{mL}$. Anti-rhGH antibodies were eluted through a second column with helix 4 peptide immobilized to sepharose. After dehydration the antibodies final concentration was $0.948 \mathrm{mg} / \mathrm{mL}$. This antibody was used to capture hGH and rhGH. The antibodies that did not recognize helix 4 peptide were conjugated to HRPO and the best dilution used in all ELISAs was $1: 1000$.

\section{Sandwich ELISA}

The rhGH saturation curve was constructed with the absorbance data obtained using fresh dilutions of rhGH (Genotropin, Pharmacia) preparations (Figure 1). The results were obtained through absorbance plot against rhGH concentration. There were no differences between plates that were coated just before use and those that were frozen until up to six weeks before the assay. The working range was at $1.95 \mathrm{ng} / \mathrm{mL}$ to $31.5 \mathrm{ng} / \mathrm{mL}$ and the limit of detection tested $(0.12 \mathrm{ng} / \mathrm{mL})$ was statistically different from the blank $(P=.024)$.

Intra-assay precision control was assessed by measuring 4 groups of sera pools corresponding to time points basal (B), 60, 90, and 120 minutes. Each pool was measured 16 times in the same plate. The interassay coefficient was obtained by analyzing each of the 4 time points in the 17 different assays (Table 1).

The accuracy was evaluated by analytical recovery in which a known rhGH concentration $(6.54 \mathrm{ng} / \mathrm{mL})$ was added to 4 patient samples ranging from 2.76 to $14.08 \mathrm{ng} / \mathrm{mL}$. The measured values were within $96.02 \%$ and $103.82 \%$ (Table 2 ).

The linearity of this sandwich ELISA was estimated through the quantification of 4 serum samples (B, 60, 90,
Table 1. Precision of hGH levels measured by anti-helix 4 sandwich ELISA.

\begin{tabular}{l|c|c|c|c}
\hline Assay & $\begin{array}{c}\text { Time points } \\
(\mathrm{min})\end{array}$ & $\begin{array}{c}\text { Mean } \\
(\mathrm{ng} / \mathrm{mL})\end{array}$ & $\begin{array}{c}\mathrm{SD} \\
(\mathrm{ng} / \mathrm{mL})\end{array}$ & $\begin{array}{c}\mathrm{CV} \\
(\%)\end{array}$ \\
\hline Intra-assay & Baseline & 2.37 & 0.15 & 6.33 \\
& 60 & 8.16 & 0.37 & 4.53 \\
& 90 & 14.62 & 0.81 & 5.54 \\
& 120 & 7.54 & 0.47 & 6.23 \\
Interassay & Baseline & 2.55 & 0.18 & 7.06 \\
& 60 & 8.67 & 0.52 & 6.00 \\
& 90 & 14.87 & 1.23 & 8.27 \\
& 120 & 7.79 & 0.52 & 6.67 \\
\hline
\end{tabular}

TABLE 2. Analytical recovery of rhGH.

\begin{tabular}{lccrc}
\hline Sample & Baseline & \multicolumn{1}{c}{60} & \multicolumn{1}{c}{90} & \multicolumn{1}{c}{120} \\
\hline hGH $(\mathrm{ng} / \mathrm{mL})$ & 2.76 & 8.94 & 14.08 & 7.52 \\
rhGH added (ng/mL) & 6.54 & 6.54 & 6.54 & 6.54 \\
Measured hGH level (ng/mL) & 6.28 & 6.62 & 6.79 & 6.45 \\
Recovery (\%) & 96.02 & 101.22 & 103.82 & 98.62 \\
\hline
\end{tabular}

and 120 minutes) from a single patient with known hGH concentrations that were diluted with ewe serum (ewe GH is not recognized by anti-rhGH antibody). Serum concentration with less than $3 \mathrm{ng} / \mathrm{mL}$ lost linearity.

Human prolactin (hPRL) has several similarities with hGH such as structure and function [19], however, helix 4 peptide has only 4 amino acids in common with hPRL. There was no cross-reactivity between hPRL from SigmaAldrich, (St Louis, Mo) (3.9 to $500 \mathrm{ng} / \mathrm{mL}$ ) or hPRL from Abbott calibrator, (Abbott Park, Ill) (1.56 to $200 \mathrm{ng} / \mathrm{mL}$ ) (Figure 2).

\section{Comparison with IRMA and ICMA}

The measured sera hGH from 109 patients were obtained using the present assay and then compared with the results from an IRMA (MaiaClone, Biodata Diagnostics). Although the hGH concentrations obtained for both types of assays, for each of the 4 time points of the clonidine test, were highly correlated ( $r$-values ranging from 0.92 to 0.98 ), samples from 24 patients were significantly different between these 2 assays. In order to clarify the differences between IRMA and our sandwich ELISA for these 24 patients, their sera were quantified by a commercial ICMA (Immulite 2000, Diagnostic Products Corporation, Los Angeles, Calif). The results revealed by ICMA did not clarify the discrepancies found between sandwich ELISA and IRMA (Table 3).

Despite the differences among these 3 assays, the correlation $(r)$ ranged from 0.93 (between ELISA and ICMA) to 0.89 (between ICMA and IRMA). Those patients (3/109, 2.7\%, 2 boys and 1 girl) with growth retardation, who had normal or high hGH levels revealed by IRMA and low levels with ELISA, are being further investigated for possible hGH gene mutations. Patients 4, 13, and 15 


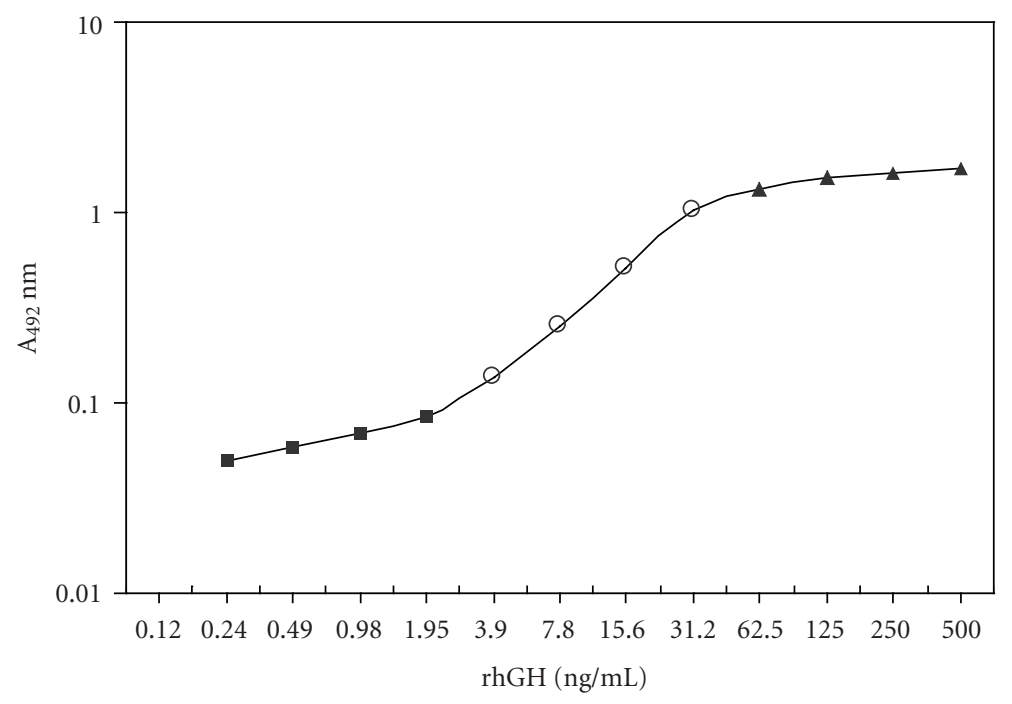

Figure 1. Saturation curve for rhGH. The working range was $(\bigcirc)$ from 1.95 to $31.25 \mathrm{ng} / \mathrm{mL}$. A trend to linearity can be observed at the interval between 0.24 to $1.95 \mathrm{ng} / \mathrm{mL}(\boldsymbol{\bullet})$. A trend to a plateau $(\boldsymbol{\Lambda})$ can be found at high $\mathrm{rhGH}$ concentration.

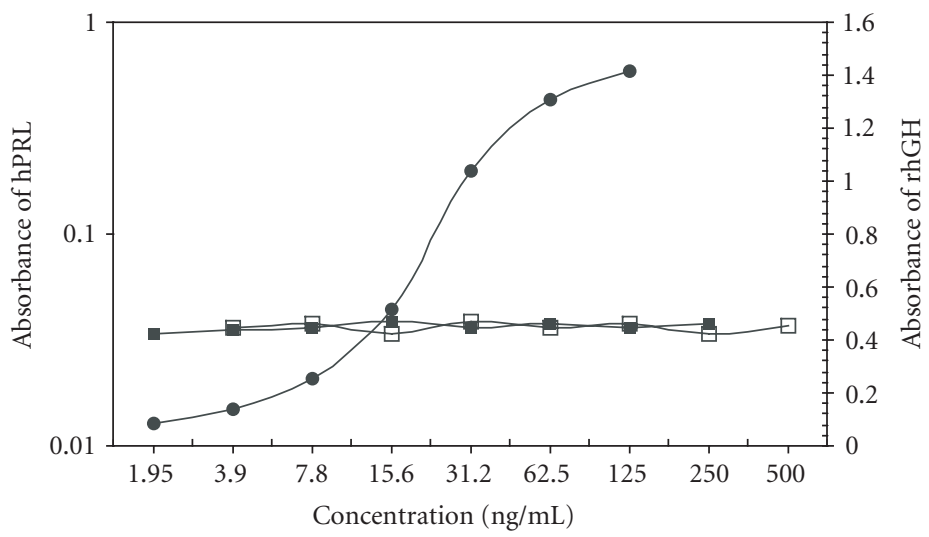

Figure 2. Estimation of cross-reactivity between both human prolactin, hPRL Sigma ( $\square$ ) and hPRL Abbott ( $\mathbf{\square})$, and the rhGH Genotropin, Pharmacia $(\bullet)$.

(Table 3), who have presented growth retardation and low levels of hGH measured by ELISA, are presently being investigated for possible mutation in the hGH gene. One of these patients presented low levels of insulin growth factor 1 , which were normalized after an rhGH test.

\section{DISCUSSION}

Our study proposes a protocol for production of polyclonal antibodies with monoclonal antibodies characteristics, in which small synthetic peptides are selected for purification without participating in the animal immunization process. In addition, this approach provides much higher amounts of animal immunoglobulins than that obtained through the use of hybridoma.

One of the landmarks in the design of hormone immunoassays is the specificity of the antibody for the selected epitope. When such an epitope plays an important role in binding to the hormone receptor, the assay may be used to estimate immunoreactivity and bioactivity. Subtle changes in a small epitope caused by point mutations should be able to prevent its recognition by this antibody. Usually, the immunoreactivity is measured without presenting any evidence whether the peptide is biologically active or not [20].

The need for a bioactive assay has been proposed by Strasburger [21]. de Vos et al [3] have reported on the importance of binding sites 1 and 2 of hGH molecule to dimerization of hGHR; other studies have shown consequences of mutations in these sites [10] characterized by Kowarski's syndrome [9]. Rowlinson et al [22] have reported three site 1 mutants, which had decreased bioactivity mainly when the center of helix 4 was involved.

In the present study, we have described a sandwich ELISA for the determination of hGH levels in which horse polyclonal antibodies anti-rhGH was produced, conjugated to HRPO or further purified using immunoaffinity chromatography. The main feature of this ELISA is the use 
TABle 3. Differences found among ELISA, ICMA, and IRMA.

\begin{tabular}{|c|c|c|c|}
\hline Patient & ELISA (ng/mL) & ICMA (ng/mL) & IRMA (ng/mL) \\
\hline 1 & 19.6 & 22.2 & 31.6 \\
\hline 2 & 4.0 & 3.2 & 1.9 \\
\hline 3 & 12.0 & 13.2 & 15.5 \\
\hline 4 & 4.1 & 12.4 & 12.0 \\
\hline 5 & 19.1 & 23.0 & 10.7 \\
\hline 6 & 24.5 & 31.2 & 35.5 \\
\hline 7 & 11.0 & 12.2 & 7.0 \\
\hline 8 & 1.6 & 1.9 & 0.45 \\
\hline 9 & 9.1 & 8.8 & 5.0 \\
\hline 10 & 9.8 & 8.2 & 6.6 \\
\hline 11 & 10.5 & 10.3 & 15.5 \\
\hline 12 & 0.3 & 1.8 & 1.6 \\
\hline 13 & 6.0 & 17.5 & 21.9 \\
\hline 14 & 6.7 & 9.2 & 10.0 \\
\hline 15 & 4.9 & 15.2 & 11.6 \\
\hline 16 & 11.1 & 19.7 & 14.2 \\
\hline 17 & 10.2 & 9.9 & 19.7 \\
\hline 18 & 3.5 & 2.8 & 5.0 \\
\hline 19 & 19.3 & 20.2 & 26.5 \\
\hline 20 & 1.3 & 1.8 & 0.9 \\
\hline 21 & 13.9 & 19.0 & 10.8 \\
\hline 22 & 2.0 & 4.9 & 4.5 \\
\hline 23 & 34.0 & 36.0 & 42.9 \\
\hline 24 & 35.2 & 34.0 & 40.0 \\
\hline
\end{tabular}

of an antibody against helix 4 , a region that contributes to binding site 1 of hGH. From horse serum with high antibodies titres $(1: 256000)$ we isolated antibodies that recognize this portion of binding site 1 . For this purpose, a synthetic peptide (AA 166-181), corresponding to a portion of helix 4, was immobilized to the affinity column.

The horse antibodies fraction that recognizes helix 4 was purified and used as a capture antibody. The second antibody does not bind to the helix 4 epitope, which is a desirable feature to prevent competition for the same epitope of the capture antibody. This marker antibody, conjugated to HRPO according to Nakane and Kawaoi [18], was used at a $1: 1000$ dilution following assay standardization.

We noticed that with hGH concentration between 3.3 and $11 \mathrm{ng} / \mathrm{mL}$ there was a linearity close to $100 \%$ and the accuracy had values above $0.98 \mathrm{ng} / \mathrm{mL}$. The reproducibility was assessed through intra- and interassay variation coefficients ranging from $4.53 \%$ to $6.33 \%$ and from $6.0 \%$ to $8.27 \%$, respectively. The analytical recovery ranging from $96.02 \%$ to $103.82 \%$ demonstrated acceptable values to conventional assays.

Site 1 of hGH and hPRL presents 12 different residues [17], which may be the reason why our assay did not cross-react with hPRL. We used concentrations of hPRL up to $500 \mathrm{ng} / \mathrm{mL}$ and no cross-reactivity was observed.
This had to be documented because some children or adult patients under stress conditions have high levels of serum hPRL. In addition, some pituitary adenomas may produce both hormones, and a distinction between hGH and hPRL levels is then necessary.

After standardization of sandwich ELISA, we quantified 436 samples from 109 children ( 4 samples/child) who were submitted to a pharmacological test of clonidine and had hGH levels determined by IRMA. The obtained results were compared to those obtained with our sandwich ELISA. Despite the high correlation ( $r$-values ranging from 0.92 to 0.98$), 24$ patients had, between these two assays, different hGH concentrations. These divergences required further tests in a commercial laboratory that employs automated ICMA. The correlation coefficients were positive, with $r$ ranging from 0.93 (between ELISA and ICMA) to 0.89 (between ICMA and IRMA), but this analysis did not clarify the discrepancies found among these assays (Table 3). Differences in the methodology and/or samples conditions may justify such differences. It is not surprising that assays with different protocols produce unequal results. These discrepancies are attributed to the calibrator [23], to GHBP presence [24, 25], and, mainly, to multiple isoforms of $\mathrm{hGH}$ and to the specificity of antibodies to several epitopes [21, 23, 25, 26]. Furthermore, in the circulation there are some disulfide dimers of hGH that are less bioactive [27] and several proteolytically degraded fragments without biological activity [28], but they could exhibit immunoreactivity depending on the antibody [27]. A group of 3 patients (2.7\%, 2 boys and 1 girl), both growing under the third percentile curve, had normal or high hGH levels based on IRMA and low levels using ELISA, which may suggest that these hGH isoforms could be mutant ones. Further studies using DNA sequencing analysis of the hGH gene are necessary to confirm this hypothesis.

While most assays were not designed to draw any conclusion about hGH bioactivity $[5,6,7,8]$, one study was able to present a sophisticated immunofunctional assay [4], but it is many times more expensive than the ELISA proposed in this study. This IFA uses a monoclonal antibody for receptor binding site 2 and biotin-labeled human recombinant GH-binding protein (GHBP). The reason for raising antibodies to sites 1 or 2 seems to be much more of a limitation in the methodology, for its sheer difficulty in their obtaining. In our approach only one of the antibodies tested anti-helix 4 was considered appropriate to be used as a capture antibody. We may predict, based on the observed similarity of the results obtained in 3 samples from 82 patients, and similar differences observed among ELISA, ICMA, and IRMA in 24 patients (Table 3), that there must be more than one epitope in helix 4, probably also not involved in GHBP binding site. Site 2 is constituted by a small number of amino acids while the interface between hGH binding site 1 and the hGHR involves 31 amino acids [14] distributed among helices 1 and 4 and loop 1 [3]. A simple approach used to select the capture polyclonal antibodies was the most important feature in 
the technique used to develop this ELISA. To some extent, the smaller the size of the peptide used, the closer the purified antibodies from a monoclonal antibody will be. Obviously, this seems not to be the case in our present study because the 16-residue peptide is large enough to present a number of possible epitopes. Six amino acids in this region (Asp171, Lys172, Thr175, Phe176, Arg178, and Ile179) contribute to binding of hGH to the hGHR [15]. The other important residues involved in binding site 1 were not included, as intended, because the other affinity columns prepared with the peptides containing these residues were not able to recognize anti-rhGH polyclonal antibodies.

The immunoaffinity chromatography has become a standard technique in which primary amino groups from proteins are bound to gel matrices from agarose [29]. The purification method using a synthetic peptide is efficient for selection of a certain population of antibodies that are necessary for quantifying any protein whose epitope plays an important role in the protein function. We can conclude that this sandwich ELISA is an inexpensive and efficient method that can be easily adapted to the automated devices for confirmation of hGH deficiency.

\section{ACKNOWLEDGMENTS}

This study was supported by CNPq (Brazil). We are grateful to Dr. Carlos Chávez Olórtegui from Fundação Ezequiel Dias, Belo Horizonte, Brazil, for his contribution with valuable technical expertise.

\section{REFERENCES}

[1] Rappaport R, Czernichow R. Disorders of growth hormone and prolactin secretion. In: Bertrand J, Rappaport R, Sizonenko PC, eds. Pediatric Endocrinology. Baltimore, Md: Williams \& Wilkins; 1993.

[2] Cunningham BC, Ultsch M, de Vos AM, Mulkerrin MG, Clauser KR, Wells JA. Dimerization of the extracellular domain of the human growth hormone receptor by a single hormone molecule. Science. 1991;254(5033):821-825.

[3] de Vos AM, Ultsch M, Kossiakoff AA. Human growth hormone and extracellular domain of its receptor: crystal structure of the complex. Science. 1992;255(5042):306-312.

[4] Strasburger CJ. Methods in determining growth hormone concentrations: an immunofunctional assay. Pediatrics. 1999;104(4):1024-1028.

[5] Tanaka T, Shiu RP, Gout PW, Beer CT, Noble RL, Friesen HG. A new sensitive and specific bioassay for lactogenic hormones: measurement of prolactin and growth hormone in human serum. J Clin Endocrinol Metab. 1980;51(5):1058-1063.

[6] Dattani MT, Hindmarsh PC, Pringle PJ, Brook CG, Marshall NJ. The measurement of growth hormone bioactivity in patient serum using an eluted stain assay. J Clin Endocrinol Metab. 1995; 80(9):2675-2683.

[7] Ishikawa M, Nimura A, Horikawa R, et al. A novel specific bioassay for serum human growth hormone. J Clin Endocrinol Metab. 2000;85(11):4274-4279.

[8] Rowland JE, Marshall NJ, Leung KC, et al. A novel bioassay for human somatogenic activity in serum samples supports the clinical reliability of immunoassays. Clin Endocrinol (Oxf). 2002;56(4):475485.

[9] Kowarski AA, Schneider J, Ben-Galim E, Weldon VV, Daughaday WH. Growth failure with normal serum RIA-GH and low somatomedin activity: somatomedin restoration and growth acceleration after exogenous GH. J Clin Endocrinol Metab. 1978;47(2):461-464.

[10] Takahashi Y, Shirono H, Arisaka O, et al. Biologically inactive growth hormone caused by an amino acid substitution. J Clin Invest. 1997;100(5):1159-1165.

[11] Miles LE, Hales CN. Immunoradiometric assay of human growth hormone. Lancet. 1968;2(7566):492493.

[12] Albertsson-Wikland K, Jansson C, Rosberg S, Novamo A. Time-resolved immunofluorometric assay of human growth hormone. Clin Chem. 1993;39(8):1620-1625.

[13] Iranmanesh A, Grisso B, Veldhuis JD. Low basal and persistent pulsatile growth hormone secretion are revealed in normal and hyposomatotropic men studied with a new ultrasensitive chemiluminescence assay. J Clin Endocrinol Metab. 1994;78(3): 526-535.

[14] Clackson T, Wells JA. A hot spot of binding energy in a hormone-receptor interface. Science. 1995; 267(5196):383-386.

[15] Cunningham BC, Wells JA. High-resolution epitope mapping of hGH-receptor interactions by alaninescanning mutagenesis. Science. 1989;244(4908): 1081-1085.

[16] Kates SA, Albericio A. Solid-phase Synthesis: A Practical Guide. New York, NY: Marcel Dekker; 2000.

[17] Goffin V, Shiverick KT, Kelly PA, Martial JA. Sequence-function relationships within the expanding family of prolactin, growth hormone, placental lactogen, and related proteins in mammals. Endocr Rev. 1996;17(4):385-410.

[18] Nakane PK, Kawaoi A. Peroxidase-labeled antibody. A new method of conjugation. J Histochem Cytochem. 1974;22(12):1084-1091.

[19] Nicoll CS, Mayer GL, Russell SM. Structural features of prolactins and growth hormones that can be related to their biological properties. Endocr Rev. 1986;7(2):169-203.

[20] Radetti G, Bozzola M, Pagani S, Street ME, Ghizzoni L. Growth hormone immunoreactivity does not reflect bioactivity. Pediatr Res. 2000;48(5):619-622. 
[21] Strasburger CJ. Antigenic epitope mapping of the human growth hormone molecule: a strategy to standardize growth hormone immunoassays. Acta Paediatr Scand Suppl. 1990;370:82-86.

[22] Rowlinson SW, Barnard R, Bastiras S, Robins AJ, Brinkworth R, Waters MJ. A growth hormone agonist produced by targeted mutagenesis at binding site 1. Evidence that site 1 regulates bioactivity. J Biol Chem. 1995;270(28):16833-16839.

[23] Celniker AC, Chen AB, Wert RM Jr, Sherman BM. Variability in the quantitation of circulating growth hormone using commercial immunoassays. J Clin Endocrinol Metab. 1989;68(2):469-476.

[24] Baumann G. Growth hormone binding proteins and various forms of growth hormone: implications for measurements. Acta Paediatr Scand Suppl. 1990;370:72-80.

[25] Granada ML, Sanmarti A, Lucas A, et al. Assaydependent results of immunoassayable spontaneous 24-hour growth hormone secretion in short children. Acta Paediatr Scand Suppl. 1990;370:63-70.

[26] Chatelain P, Bouillat B, Cohen R, et al. Assay of growth hormone levels in human plasma using commercial kits: analysis of some factors influencing the results. Acta Paediatr Scand Suppl. 1990;370:56-61.

[27] Brostedt P, Luthman M, Wide L, Werner S, Roos P. Characterization of dimeric forms of human pituitary growth hormone by bioassay, radioreceptor assay, and radioimmunoassay. Acta Endocrinol (Copenh). 1990;122(2):241-248.

[28] Strasburger CJ. Implications of investigating the structure-function relationship of human growth hormone in clinical diagnosis and therapy. Horm Res. 1994;41(suppl 2):113-119.

[29] Axen R, Porath J, Ernback S. Chemical coupling of peptides and proteins to polysaccharides by means of cyanogen halides. Nature. 1967;214(95):1302-1304.

* Corresponding author.

Current address: Department of Pediatrics, Hospital de Clinicas, Frederal University of Paraná, Rua General Carneiro, 181 Curitiba, PR, Brazil E-mail: bonaldf@yahoo.com.br Fax: +55 4130293204 16; Tel: +55 413029320416 

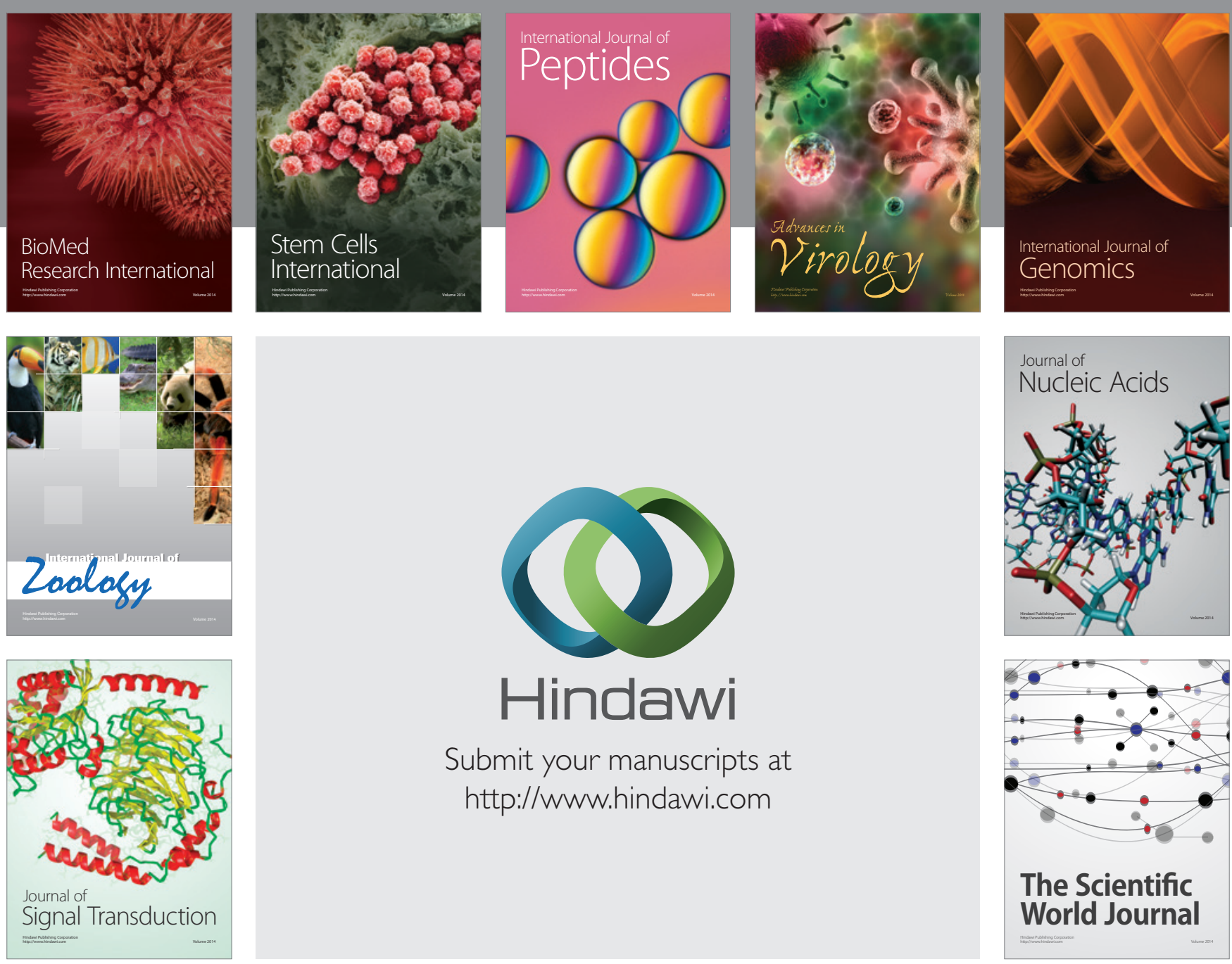

Submit your manuscripts at

http://www.hindawi.com
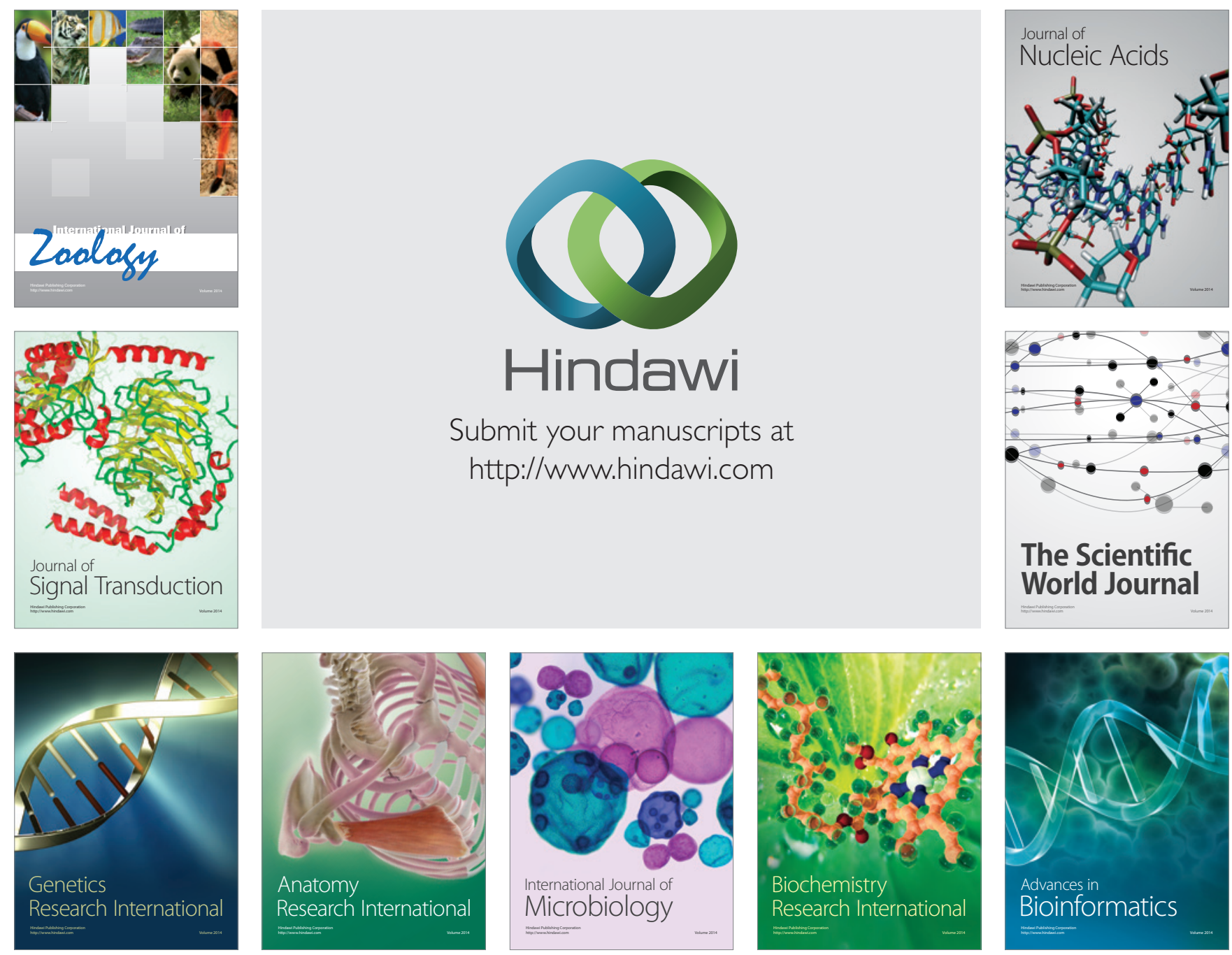

The Scientific World Journal
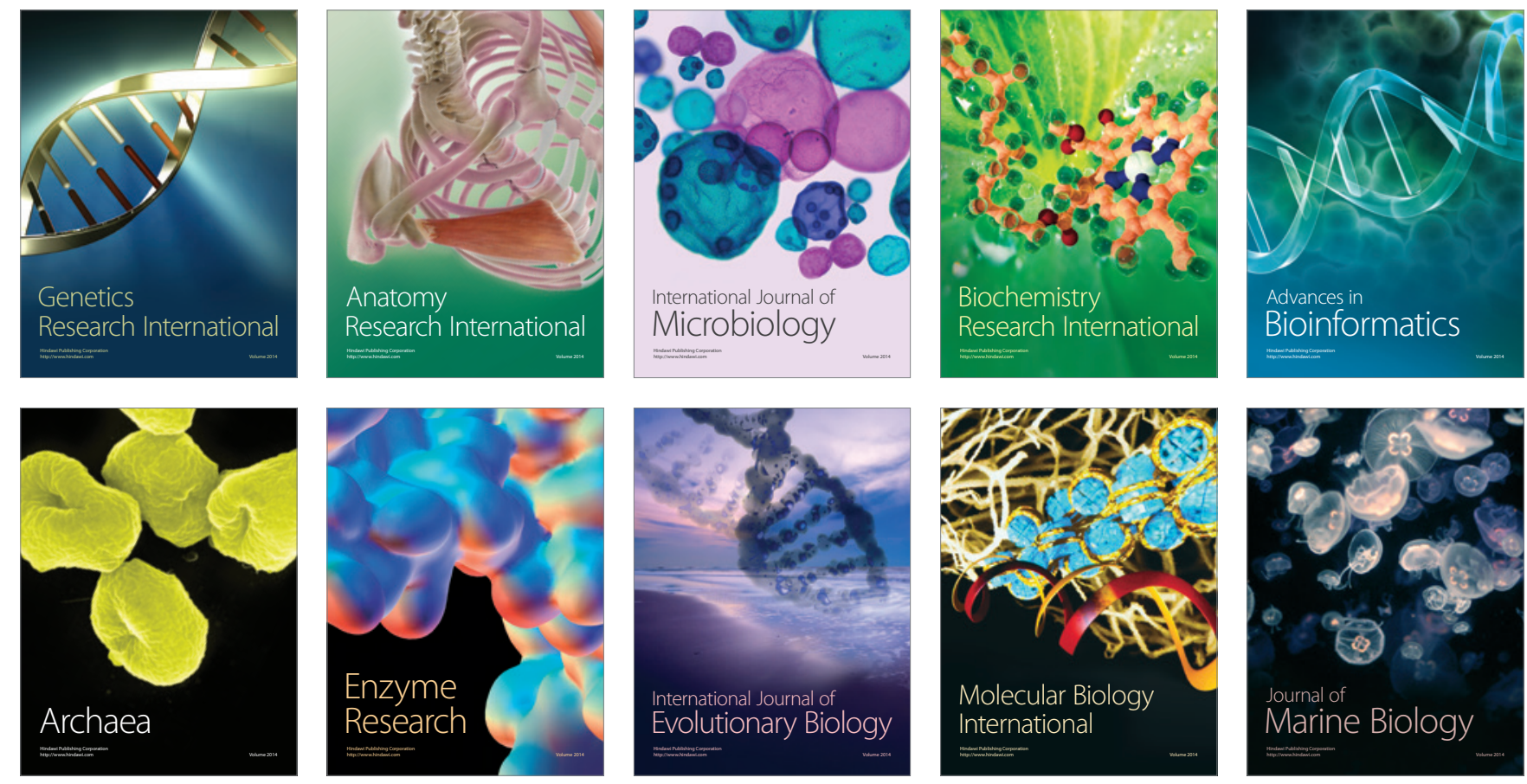